\title{
PENGELOLAAN ADMINISTRASI BPHTB DALAM MENINGKATKAN PENDAPATAN ASLI DAERAH (PAD) DI KOTA PALEMBANG TAHUN 2018
}

\author{
Yuliana $^{1}$, Yuslainiwati ${ }^{2}$, Amir Mahmud ${ }^{3}$ \\ ${ }^{1)}$ Staf pengajar Magister Administrasi Publik Program Pascasarjana \\ Universitas Sjakhyakirti Palembang \\ 2) Staf pengajar Magister Administrasi Publik Program Pascasarjana \\ Universitas Sjakhyakirti Palembang \\ ${ }^{3)}$ Staf pengajar Magister Administrasi Publik Program Pascasarjana \\ Universitas Sjakhyakirti Palembang \\ Email : yuli_72@yahoo.co.id, yuslainiw@gmail.com, amir15mahmud@gmail.com
}

\begin{abstract}
ABSTRAK
Pajak Bea Perolehan Hak Atas Tanah dan Bangunan (BPHTB) menupakan pajak perolehan hak atas tanah dan bangunan yang ditetapkan menjadi pajak daerah sejak Januari 2011. Tujuan penelitian ini dilakukan untuk mengetahui pengelolaan administrasi Bea Perolehan Hak Atas Tanah dan Bangunan oleh Dinas Pendapatan Daerah Kota Palembang tahun 2018 dan untuk mengetahui faktor-faktor apa saja yang menjadi penghambat dalam pemungutan pajak Bea Perolehan Hak Atas Tanah dan Bangunan di Palembang. Metode yang digunakan dalam penelitian ini adalah metode penelitian deskriptif kualitatif. Sumber Data yang diperoleh dari data primer melalui wawancara dan observasi, data sekunder melalui arsip, laporan, buku dan sumber lainnya yang berkaitan dengan pemungutan pajak BPHTB. Setelah data-data tersebut didapat kemudian data tersebut ditampilkan dan diberi interpretasi serta dianalisis secara mendalam sesuai dengan aspek-aspek yang terdapat dalam penelitian ini. Penelitian ini melibatkan satu instansi di lingkungan Pemerintah Kota Palembang yaitu Dinas Pendapatan Daerah Kota Palembang. Berdasarkan hasil penelitian tersebut saran yang dapat diberikan antara lain mengadakan pelatihan bagi petugas pemungut pajak, bagi pihak DISPENDA sebaiknya memberikan sosialisasi dan informasi kepada masyarakat, terutama tentang pajak BPHTB, karena pajak BPHTB merupakan pajak baru untuk daerah yang sebelumnya merupakan pajak pusat, merubah sistem yang digunakan yakni sistem manual menjadi sistem komputerisasi, bagi wajib pajak BPHTB diharapkan lebih transparan dan lebih jujur dalam memberi data pajak dan bagi wajib pajak yang melanggar agar dapat dikenakan sanksi yang tegas.
\end{abstract}

Kata Kunci: Pengelolaan Administrasi Pajak, PajakBea Perolehan Hak Atas Tanah dan Bangunan

\section{PENDAHULUAN}

Pembayaran pajak merupakan perwujudan dari kewajiban kenegaraan dan peran serta Wajib Pajak untuk secara langsung dan bersama-sama melaksanakan kewajiban perpajakan untuk pembiayaan negara dan pembangunan nasional. Sesuai falsafah UndangUndang perpajakan, "membayar pajak bukan hanya merupakan kewajiban, tetapi merupakan hak dari setiap warga Negara untuk ikut berpartisipasi dalam bentuk peran serta terhadap pembiayaan negara dan pembangunan nasional." Tanggung jawab atas kewajiban pembayaran pajak, sebagai pencerminan kewajiban kenegaraan di bidang perpajakan berada pada anggota masyarakat sendiri untuk memenuhi kewajiban tersebut. Hal tersebut sesuai dengan sistem self assessment yang dianut dalam Sistem Perpajakan Indonesia. 
Sejak diberlakukannya UU No.28 tahun 2009 tentang Pajak Daerah dan Retribusi Daerah, PBB sektor perkotaan dan pedesaan dan BPHTB yang tadinya merupakan pajak pusat dialihkan menjadi pajak daerah. Pajak Bea Perolehan Hak atas Tanah dan Bangunan atau yang biasa dikenal dengan BPHTB resmi sepenuhnya menjadi pajak daerah (local tax) per tanggal 1 Januari 2011. Pengalihan wewenang pemungutan atau devolusi BPHTB dari Pemerintah Pusat kepada Pemerintah Kabupaten/Kota adalah sesuai dengan amanat Undang-Undang Nomor 28 tahun 2009 tentang Pajak Daerah dan Retribusi Daerah (PDRD). Pajak BPHTB ini didasari dengan landasan hukum UU No 20 Tahun 2000 yang menjelaskan bahwa Pajak Bea Perolehan Hak Atas Tanah dan Bangunan adalah pajak yang dikenakan atas perolehan hak atas tanah dan atau bangunan, yang selanjutnya dialihkan dari pajak pusat menjadi pajak daerah. Dengan demikian per tanggal 1 Januari 2011 Kantor Pelayanan Pajak Pratama (KPP Pratama) sudah tidak lagi melayani pengelolaan pelayanan BPHTB, sehingga wajib pajak yang akan melaporkan pembayaran BPHTB sehubungan dengan proses transaksi properti yang dilakukannya akan langsung ditangani oleh Pemerintah Kabupaten/Kota setempat.

Pada Dinas Pendapatan Daerah yang telah melakukan kebijakan ini per tanggal 1 Januari 2011, dituntut lebih kreatif dalam menggali pendapatan dari bea perolehan hak atas tanah dan bangunan (BPHTB). Karena, tahun 2013 pendapatan pemerintah dari BPHTB itu menukik tajam. Dari target Rp80,5 miliar, sekarang baru terkumpul Rp56 miliar atau 68 persen dari target. Jumlah ini jauh menunun dibanding tahun 2012, yang terealisasi Rp99 miliar dari target Rp68 miliar. Jadi, over target dengan persentase 145 persen.

Menurut Kepala Dinas Pendapatan Daerah Kota Palembang Agus Kelana, penurunan pendapatan karena tarif Nilai Jual Objek Pajak sudah tidak sesuai lagi, Nilai Jual Objek Pajak yang selanjutnya disingkat NJOP adalah harga rata-rata yang diperoleh dari transaksi jual beli, NJOP ditentukan melalui perbandingan harga dengan objek lain yang sejenis, atau nilai perolehan baru atau NJOP pengganti. NJOP saat ini sudah jauh di bawah harga pasaran objek pajak, ini terjadi karena setiap transaksi pembelian tanah dari wajib pajak mayoritas tanpa lampiran surat bukti setor dari Badan Pertanahan Nasional (BPN) ke Dispenda.

\section{Rumusan Masalah}

Berdasarkan latar belakang yang telah di uraikan di atas, maka dapat dirumuskan:

Bagaimana pengelolaan administrasi BPHTB dalam meningkatkan Pendapatan Asli Daerah (PAD) kota palembang tahun 2018?

\section{Tujuan Penelitian}

Penelitian ini bertujuan untuk:

Untuk mengetahui bagaimana pengelolaan administrasi BPHTB dalam meningkatkan PAD terhadap wajib pajak di kota Palembang.

\section{Manfaat Penelitian}

Berdasarkan tujuan yang ingin dicapai dalam penelitian, maka manfaat yang diharapkan dalam penelitian ini adalah sebagai berikut:

\section{1) Manfaat Teoritis}

Penelitian ini di harapkan dapat memberikan manfaat dan menambah wawasan, pengetahuan, serta pengalaman terhadap penerapan pajak dalam perkembangan Ilmu Administrasi Negara, khususnya Keuangan Negara.

\section{2) Manfaat Praktis}

Penelitian ini diharapkan dapat menjadi referensi dalam menentukan solusi terbaik untuk meningkatkan kepatuhan dan kesadaran masyarakat/wajib pajak dalam membayar Pajak Bea Perolehan Hak Atas Tanah Dan Bangunan (BPHTB) di kota Palembang.

\section{LANDASANTEORI}

Landasan teori adalah teori-teori relevan yang dapat digunakan untuk menjelaskan tentang variable yang akan diteliti, serta sebagai dasar untuk member jawaban sementara terhadap rumusan masalah yang diajukan (hipotesis) ddan 
penyusunan instrument penelitian (suyiono, 2010:326).

Menurut Drs. Tjahja Supriatna (2000), definisi keuangan daerah adalah kemampuan pemerintah daerah untuk mengawasi daerah serta mengelola mulai dari merencanakan, melaksanakan, mengawasi, mengendalikan, dan mengevaluasi berbagai sumber keuangan sesuai dengan kewenangannya dalam rangka pelaksanaan asas desentralisasi, dekosentrasi dan tugas pembantuan di daerah yang diwujudkan dalam bentuk anggaran pendapatan dan belanja daerah (PBD).

Sedangkan menurut Peraturan Pemerintah No. 105 Tahun 2000, keuangan daerah adalah "Semua hak dan kewajiban daerah dalam rangka penyelenggaraan pemerintah daerah yang dapat dinilai dengan uang termasuk di dalamnya segala bentuk kekayaan yang berhubungan dengan hak dan kewajiban daerah tersebut, dalam kerangka anggaran pendapatan dan belanja daerah (APBD)"

Di dalam Undang-Undang yang mengatur Keuangan Negara, terdapat penegasan di bidang pengelolaan keuangan yang berimplikasi pada pengaturan pengelolaan keuangan daerah, yaitu bahwa Kepala daerah (gubemur/bupati/ walikota) adalah pemegang kekuasaan pengelolaan keuangan daerah dan bertanggungjawab atas pengelolaan keuangan daerah sebagai bagian dari kekuasaan pemerintahan daerah. Dalam melaksanakan kekuasaannya, kepala daerah melimpahkan sebagian atau seluruh kekuasaan keuangan daerah kepada para pejabat perangkat daerah. Dengan demikian pengaturan pengelolaan dan pertanggungjawaban keuangan daerah melekat dan menjadi satu dengan pengaturan pemerintahan daerah, yaitu dalam Undang-Undang mengenai Pemerintahan Daerah.

$$
\text { Menurut Wardoyo (1990;14), }
$$
pengelolaan sama artinya dengan manajeman, Wardoyo mengatakan dalam mencapai suatu pengelolaan yang baik harus memiliki perencanaan, pengorganisasian, penggerakan, dan pengawasan untuk mencapai tujuan yang telah ditetapkan sebelumnya.
Menurut George R Terry mendefinisikan manajemen dalam bukunya Principles of Management yaitu "Suatu proses yang membedakan atas perencanaan, pengorganisasian, penggerakan dan pengawasan dengan memanfaatkan baik ilmu maupun seni demi mencapai tujuan yang telah ditetapkan sebelumnya". Dari definisi Terry itulah bisa melihat fungsi manajemen menurutnya. Berikut ini adalah fungsi manajemen menurut Terry:

1. Perencanaan (planning) yaitu sebagai dasar pemikiran dari tujuan dan penyusunan langkah-langkah yang akan dipakai untuk mencapai tujuan. Merencanakan berarti mempersiapkan segala kebutuhan, memperhitungkan matang-matang apa saja yang menjadi kendala, dan menumuskan bentuk pelaksanaan kegiatan yang bermaksuud untuk mencapai tujuan.

2. Pengorganisasian (organization) yaitu sebagai cara untuk mengumpulkan orang-orang dan menempatkan mereka menurut kemampuan dan keahliannya dalam pekerjaan yang sudah direncanakan.

3. Penggerakan (actuating) yaitu untuk menggerakan organisasi agar berjalan sesuai dengan pembagian kerja masing-masing serta menggerakan seluruh sumber daya yang ada dalam organisasi agar pekerjaan atau kegiatan yang dilakukan bisa berjalan sesuai rencana dan bisa memcapai tujuan.

4. Pengawasan (controlling) yaitu untuk mengawasi apakah gerakan dari organisasi ini sudah sesuai dengan rencana atau belum. Serta mengawasi penggunaan sumber daya dalam organisasi agar bisa terpakai secara efektif dan efisien tanpa ada yang melenceng dari rencana.

\section{METODE PENELITIAN}

Menurut Moh. Nazir (1988:51) Metode penelitian merupakan cara utama yang digunakan peneliti untuk mencapai tujuan dan menentukan jawaban atas masalah yang diajukan. Jenis penelitian yang digunakan dalam penelitian ini adalah metode penelitian kualitatif. Pendekatan kualitatif adalah penelitian yang bermaksud untuk memahami masalah tentang apa yang dialami oleh subyek pajak penelitian secara menyelunuh, dengan cara deskripsi dan dengan memanfaatkan berbagai 
metode alamiah. Penulis menggunakan pendekatan kualitatif karena data-data terlebih dahulu diolah untuk mendapatkan gambaran yang jelas mengenai pengelolaan administrasi dalam kegiatan pemungutan pajak Bea Perolehan Hak Atas Tanah Dan Bangunan (BPHTB). Kemudian penulis akan menganalisis apa saja permasalahan yang muncul atas pengelolaan administrasi pajak Bea Perolehan Hak Atas Tanah Dan Bangunan (BPHTB) pada Dinas Pendapatan Daerah (DISPENDA) Kota Palembang.

\section{Jenis dan Sumber Data}

Dalam hal ini jenis penelitian yang akan digunakan adalah penelitian kualitatif deskriptif, menurut Moh. Nazir $(1999,181)$ ada beberapa ciri jenis penelitian kualitatif deskriptif, yaitu :

1. Memusatkan diri pada masalah yang ada pada masa sekarang dan pada masalahmasalah yang actual

2. Daftar yang dikumpulkan disusun, dijelaskan, dan kemudian dianalisis.

Data yang di peroleh dalam penelitian tentang pengelolaan administrasi hasil pajak Bea Perolehan Hak Atas Tanah Dan Bangunan (BPHTB) pada Dinas Pendapatan Daerah Kota Palembang adalah:

1) DataPrimer adalah data yang diperoleh atau dikumpulkan langsung di lapangan oleh peneliti. Dalam penelitian ini, data diperoleh melalui wawancara dengan sumber data, yaitu Kepala Seksi bidang BPHTB pada Dinas Pendapatan Daerah Kota Palembang.

2) Data Sekunder

adalah data yang diperoleh dalam rangka melengkapi dan menunjang data primer, data ini bersumber dari dokumen berupa catatancatatan, peraturan-peraturan, keputusan, laporan, buku-buku, arsip-arsip, internet yang berkaitan dengan masalah penelitian.

Penulis menggunakan penelitian deskriptif karena penulis mencoba untuk menggambarkan bagaimana pengelolaan administrasi yang terjadi pada pemungutan pajak Bea Perolehan Hak Atas Tanah Dan Bangunan
(BPHTB) setelah menjadi pajak daerah pada Dinas Pendapatan Daerah (DISPENDA) Kota Palembang

\section{Teknik Pengumpulan Data}

Teknik pengumpulan data yang dilakukan dalam penelitian ini adalah:

1) Wawancara (interview) yaitu proses tanya jawab dalam penelitian yang berlangsung secara lisan antara dua orang atau lebih bertatap muka mendengarkan secara langsung informasiinformasi atau keterangan-keterangan.

2) Studi kepustakaan yaitu pengumpulan data melalui dokumendokumen benupa catatan-catatan, peraturanperaturan, keputusan, laporan, buku-buku, arsip-arsip, yang berkaitan dengan pemungutan pajak Bea Perolehan Hak Atas Tanah Dan Bangunan (BPHTB).

3) Studi Virtual yaitu mengumpulkan data-data serta bahanbahan yang diperoleh dari situs intemet.

\section{Teknik Analisis Data}

Dalam teknik analisis data, peneliti tertarik menganalisis permasalahan mengenai peralihan pajak Bea Perolehan Hak Atas Tanah dan Bangunan yang sebelumnya adalah pajak pusat menjadi pajak daerah. Selanjutnya, peneliti akan melakukan wawancara mendalam dengan para informan mengenai proses pengelolaan administrasi pajak BPHTB. Data dikumpulkan melalui pertanyaan-pertanyaan dengan menggunakan pedoman wawancara. Jawaban dari hasil wawancara kemudian diolah lalu disimpan untuk menghasilkan sebuah pemahaman mengenai obyek yang diteliti. Proses dalam penelitian kualitatif bukanlah sebuah proses yang linear seperti dalam penelitian kuantitatif. Menurut Prasety Irawan (2007;215) Proses penelitian dalam penelitian kualitatif terdiri atas lima tahapan, yaitu penentuan focus masalah, pengembangan kerangka teori, penentuan metodologi, analisis data dan pengambilan keputusan. 
Pengertian kualitatif deskriptif yaitu suatu prosedur penelitian yang menggunakan data deskriptif berupa kata-kata tertulis atau lisan dari orang-orang dan pelaku yang dapat diamati untuk memahami fenomena atau gejala sosial dengan lebih menitik beratkan pada gambaran yang lengkap tentang fenomena yang dikaji daripada memerincinya menjadi variabel-variabel yang saling terkait, sehingga diperoleh pemahaman yang mendalam tentang gambaaran atau paparan mengenai proses pengelolaan administrasi pajak Bea Perolehan Hak Atas Tanah dan Bangunan (BPHTB) dalam meningkatkan Pendapatan Asli Daerah (PAD) di Kota Palembang.

\section{HASIL DANPEMBAHASAN}

\section{Gambaran Umum}

\section{- Tugas Pokok dan Fungsi Dinas} Pendapatan Daerah Kota Palembang

Seiring dengan berlakunya otonomi daerah, maka Dinas Pendapatan Daerah pun mengalami berbagai perubahan, baik dan segi tugas, fungsi serta struktur dan kedudukan sebagai realisasinya, maka pada tanggal 07 Maret 2001 dikeluarkan Peraturan Daerah Kota Palembang Nomor 2 Tahun 2001 yang mengacu atau sejalan dengan ketentuan Peraturan Pemerintah Nomor 84 Tahun 2000 tentang pedoman organisasi perangkat daerah tentang pembentukan kedudukan, fungsi pokok, dan struktur organisasi Dinas Pendapatan Daerah.

1) Fungsi Dispenda Kota Palembang

a) Menumuskan kebijakan teknis di bidang pembangunan yang sifatnya mendukung secara operasional kebijakan Pemerintah Kota Palembang.

b) Memberikan perizinan dan pelaksanaan pelayanan umum sesuai dengan ketentuan perundang-undangan yang berlaku.

c) Melakukan penyuluhan mengenai pembangunan daerah, retribusi dan pendapatan asal daerah lainnya.

d) Mengadakan komunikasi, konsultasi dan kerjasama dengan unsur pemda dan instansi serta masyarakat dalam usaha pelaksanaan pembangunan. e) Perencanaan, pelaksanaan, pengkajian, pengawasan dan pengendalian evaluasi dan pengembangan pungutan pendapatan daerah

2) Tugas Pokok Dispenda Kota Palembang

a) Perumusan kebijakan teknis di bidang pembangunan.

b) Pemberian perizinan dan pelaksanaan pelayanan -dibidang pembangunan.

c) Pengelolaan urusan unit pelaksanaan Dinas Pendapatan Daerah.

d) Merencanakan dan merumuskan peningkatan sumber-sumber pendapatan daerah, memonitoring dan menguji kebenaran reatisasi kebenaran pendapatan daerah.

e) Merencanakan dan merumuskan melakukan pengawasan pelaksanaan pemungutan ash daerah.

\section{Hasil Pembahasan}

Untuk mengetahui tentang pengelolaan administrasi BPHTB dalam menunjang pendapatan asli daerah, maka terlebih dahulu perlu diketahui apa yang dimaksud dengan pengelolaan. Penulis menggunakan pendekatan pengelolaan sebagai kaitan dari fungsi manajemen yaitu perencanaan, pengorganisasian, penggerakan dan pengawasan

\section{a. Perencanaan}

Sebagai langkah awal pengelolaan pajak daerah maka kegiatan perencanaan sangat menentukan upaya pengelolaan pajak daerah. Hal ini mudah dipahami karena kegiatan tersebut akan menjadi dasar melakukan kegiatan selanjutnya.

Sebagai dasar untuk melakukan kegiatan selanjutnya maka berhasil tidaknya kegiatan berikutnya, dengan demikian dapat diambil kesimpulan bahwa peningkatan pajak daerah sangat tergantung pada kegiatan perencanaan.

Kegiatan perencanaan yang dimaksud adalah kegiatan menentukan besamya target yang ingin dicapai dari pajak BPHTB untuk satu tahun anggaran. Seperti yang telah diuraikan terdahulu bahwa untuk mengukur kegiatan perencanaan 
maka indikator yang digunakan adalah kegiatan pendaftaran, pendataan dan kegiatan penetapan.

\section{1)Pendaftaran}

Dalam upaya meningkatkan pendapatan daerah dari sektor pajak, maka langkah pertama yang perlu dilakukan dalam prosedur pendaftaran adalah menyusun Daftar Induk Wajib Pajak yang memuat nama, alamat dan Nomor Pokok Wajib PajakDaerah (NPWPD).

Langkah pertama yang perlu dilakukan dalam menyusun daftar induk wajib pajak adalah diadakan penjaringan wajib pajak, disusun serta melakukan pengukuhan dan penggolongan wajib pajak. Kemudian, kepada setiap wajib pajak yang telah didaftar dan dikukuhkan diberikan Nomor Pokok Wajib Pajak Daerah (NPWPD) yang secara permanen menjadi identitas wajib pajak yang bersangkutan dan berlaku untuk semua jenis pajak daerah yang menjadi kewajibannya.

Nomor Pokok Wajib Pajak Daerah (NPWPD) merupakan identitas yang diperlukan oleh setiap wajib pajak. Dengan identitas ini, wajib pajak dapat dengan mudah menyelesaikan segala urusan yang berkaitan dengan pemenuhan segala urusan yang berkaitan dengan pemenuhan kewajiban perpajakannya, baik mengenai pembayaran pajak, kepindahan lokasi usaha ataupun kegiatan lain yang dipersyaratkan memiliki identitas perpajakan

\section{2) Pendataan}

Kegiatan pendataan merupakan kegiatan yang sangat penting dalam kegiatannya dengan pajak daerah dalam penerimaan pendapatan asli daerah, Karena dari hasil pendataan dapat diketahui berapa besar jumlah potensi yang ada di lapangan. Dengan data tersebut para pengambil kebijakan dapat membuat estimasi dasar dalam menentukan berapa besar target penerimaan yang akan direncanakan sebagai penerimaan daerah.

Sesuai hasil penelitian yang penulis peroleh di lokasi penelitian, menunjukkan bahwa kegiatan pendataan yang dilaksanakan selama ini sudah terlaksana dengan baik.

\section{3) Penetapan}

Setelah semua tahap dilaksanakan maka langkah selanjutnya adalah menentukan target penerimaan. Data yang telah diperoleh dari kegiatan pendataan, dicatat dalam kartu data sebagai hasil akhir yang akan dijadikan dasar bagi seksi penetapan dalam menghitung besarnya target penerimaan pengelolaan pajak BPHTB.

\section{b. Pengorganisasian}

Pengorganisasian adalah suatu proses pengelompokan, penentuan dan pengaturan bermacam-macam aktivitas yang diperlukan untuk mencapai tujuan, menempatkan orang-orang untuk setiap aktivitas ini, menyediakan alat-alat yang diperlukan, menetapkam wewenang yang secara relatif didelegasikan kepada setiap individu yang akan melakukan aktivitas-aktivitas tersebut. Pengorganisasian dalam pengelolaan administrasi Bea Perolehan Hak Atas Tanah dan Bangunan pada Dinas Pendapatan Daerah Kota Palembang yaitu pembagian tugas pekerjaan.

\section{1) Pembagian Tugas Pekerjaan}

Pembagian tugas pekerjaan dalam pengelolaan administrasi pajak BPHTB ini telah disusun berdasarkan pengalaman dan kemampuan setiap individu agar mereka dalam menjalankan pembagian tugas dengan baik dan dengan semaksimal mungkin. Dengan memverifikasi dan menseleksi lebih lanjut sejumlah pegawai negeri sipil yang di ajukan agar lebih akurat.Pembagian tugas pekerjaan harus disesuaikan dengan kemampuan dan keahlian sehingga pelaksanaan kerja berjalan efektif.

Dengan adanya prinsip orang yang tepat ditempat yang tepat akan memberikan jaminan terhadap kestabilan, kelancaran dan efesiensi kerja. Pembagian kerja yang baik menupakan kunci bagi penyelengaraan kerja. Kecerobohan dalam pembagian kerja akan berpengaruh kurang baik dan mungkin menimbulkan kegagalan dalam penyelenggaraan pekerjaan, oleh karena itu, seorang manajer atau kepala yang berpengalaman akan menempatkan pembagian kerja sebagai prinsip utama yang akan menjadi titik tolak bagi prinsip-prinsip lainnya. Dinas Pendapatan Daerah Kota Palembang menyusun pembagian tugas kerja 
dengan baik dan selektif dengan efektif untuk menjalankan pengelolaan BPHTB dengan baik.

\section{2)Pengkoordinasian}

Pengkoordinasian adalah pengaturan unitunit kerja dalam suatu organisasi/ lembaga. Pengkoordinasian ini diperlukan untuk mengatur individu untuk melakukan tugas-tugas dalam mendukung suatu pencapaian tujuan yang diinginkan. Koordinasi dari semua sumber melalui proses perencanaan, pengorganisasian pimpinan, dan pengawasan agar dapat mencapai tujuan yang telah ditetapkan. Sedangkan koordinasi mengandung makna menjaga agar tugas-tugas yang telah dibagi, tidak dikerjakan menurut kehendak yang mengerjakan saja, tetapi menunut aturan sehingga tujuan yang ditentukan akan dapat dicapai.

Pengkoordinasian dalam pengelolaan administrasi BPHTB ini dilakukan oleh Dinas Pendapatan Daerah Kota Palembang yang akan berkoordinasi dengan Badan Pertanahan Nasional (BPN) Kota Palembang.

\section{c. Penggerakan}

Kegiatan penggerakan yang dimaksud adalah kegiatan mengaplikasikan target yang telah ditetapkan melalui pemungutan pajak BPHTB. Untuk mengetahui sejauh mana pergerakan kegiatan tersebut maka indikator yang digunakan adalah kegiatan penyetoran, pembukuan dan pelaporan serta penagihan.

\section{1) Penyetoran}

Mekanisme pembayaran pajak yang diterapkan oleh Dispenda Kota Palembang yaitu untuk menjamin kelancaran pembayaran pajak oleh para wajib pajak, maka Dispenda menugaskan petugas untuk turun langsung kelapangan guna memungut pajak dari masyarakat. Akan tetapi, karena keterbatasan jumlah petugas pelaksana dan luas wilayah, maka Dispenda menugaskan kepada para kepala camat untuk memungut pajak dari masyarakat di wilayahnya.

Pajak yang telah dikumpulkan selanjutnya disetor kepada bendahara Dispenda. Bendahara inilah yang kemudian menyetor hasil pajak daerah di kas daerah. Bendahara Dispenda mempunyai tugas rutin yakni setiap akhir bulan menyiapkan laporan realisasi penerimaan dan penyetoran uang untuk keperluan pemeriksaan keuangan sehingga dapat dibandingkan dengan laporan keuangan yang dibuat oleh seksi pelaporan.

\section{2) Pembukuan dan Pelaporan}

Kegiatan selanjutnya setelah penyetoran adalah pembukuan dan pelaporan. Kegiatan pelaporan menupakan pekerjaan lanjutan setelah pembukuan dan dilaksanakan setiap akhir periode bulananan, triwulan, semester, dan akhir tahun.

Seksi pembukuan selaku pelaksana akan menerima formulir atau daftar sebagai dokumen yang akan dijadikan dasar dalam pencatatan dari seksi penetapan. Dari hasil pencatatan tersebut akan diketahui jumlah penerimaan perjenis pajak, begitu pula jumlah tunggakan baik perjenis pajak maupun perwajib pajak.

\section{3) Penagihan}

Penagihan yang dimaksud disini adalah penggerakan penegakan hukum terhadap wajib pajak yang tidak menaati peraturan, dalam hal ini wajib pajak yang belum melunasi pajak yang terutang sampai dengan batas waktu yang sudah ditentukan dalam surat ketetapan.

Kegiatan penagihan dibedakan atas penagihan pasif dan penagihan aktif. Penagihan pasif dimulai dari peringatan, teguran pertama, teguran kedua sampai pada teguran ketiga, sedangkan penagihan aktif berupa proses paksa, penyitaan sampai dengan lelang sebagaimana yang diatur dalam Peraturan Menteri Keuangan Nomor 85/PMK.03/2010 tentang tata cara pelaksanaan penagihan dengan surat paksa dan pelaksanaan penagihan seketika dan sekaligus.

\section{d. Pengawasan}

Pengawasan merupakan hal yang sangat penting dalam setiap kegiatan bersama yang bertujuan untuk mencegah sedini mungkin terjadinya penyimpangan-penyimpangan, pemborosan-pemborosan dan kegagalankegagalan dalam pencapaian tujuan organisasi. Dalam kegiatan Dinas Pendapatan Daerah Kota Palembang yang berusaha untuk memasukkan 
uang kedalam kas daerah dan menutupi pengeluaran-pengeluaran daerah, termasuk di dalamnya penerimaan dari BPHTB. Apabila pengawasan dapat dilaksanakan dengan baik dalam pengelolaan BPHTB maka akan mewujudkan efesiensi, efektifitas dan kehematan serta ketertiban.

Kegiatan Pengawasan terhadap BPHTB merupakan tindakan yang sangat penting untuk menghindari penyimpangan-penyimpangan dari ketentuan yang ditetapkan dalam memenuhi target yang direncanakan dalam Anggaran Pengelolaan Keuangan Belanja Daerah Kota Palembang.

Untuk itu Dinas Pendapatan Daerah Kota Palembang sebagai salah satu dinas otonom yang diserahi tugas mengelola keuangan daerah dituntut untuk bekerja dengan sungguh-sungguh agar pemasukan dari sektor Pengelolaan Keuangan daerah khususnya pajak daerah dapat meningkat dari tahun ke tahun.

Untuk lebih jelasnya penulis akan menjelaskan bentuk pengawasan pajak daerah yang dilakukan oleh Dispenda Kota Palembang sebagai berikut.

\section{1) Pengawasan Melekat}

Pengawasan melekat yaitu serangakaian kegiatan yang bersifat sebagai pengendalian yang terus menenus dilakukan oleh atasan langsung terhadap bawahannya baik secara preventif maupun represif. Pengawasan ini dilakukan mulai dari Kepala Dispenda sampai kepada Subseksi, Kepala UPTD, camat dan unit-unit kerja yang terkait baik system pengelolaan maupun mekanisme penyetoran berdasarkan fungsi dan tugasnya masing-masing.

\section{2) Pengawasan Langsung}

Pengawasan langsung yaitu pengawasan yang dilakukan oleh pimpinan atau aparat pengasan fungsional dengan mendatangi langsung obyek yang diawasi baik pada waktu kegiatan yang sedang berlangsung maupun sesudah kegiatan dilaksanakan.

Pengawasan ini dilakukan oleh tim dari Dispenda Kota Palembang, biasanya dilakukan secara berkala maupun mendadak yang sifatnya operasional.

\section{KESIMPULAN}

Berdasarkan hasil analisis dan interprestasi data yang diperoleh melalui metode wawancara, dan studi pustaka yang telah diuraikan dalam bab sebelumnya, maka secara menyeluruh dalam Pengelolaan Administrasi Bea Perolehan Hak Atas Tanah dan Bangunan dalam meningkatkan Pendapatan Asli Daerah Kota Palembang dengan rincian kesimpulan, sebagai berikut:

1. Perencanaan terbagi menjadi tiga tahap yaitu pendaftaran, pendataan, dan penetapan. Proses pendaftran dapat menempuh dua cara yaitu sebagai langkah awal dari pelaksanaan kegiatan pendaftaran wajib pajak, petugas dalam bidang ini memanfaatkan data perpajakan yang sudah ada sebelumnya. Dengan demikian maka bagi wajib pajak yang sudah lengkap data subyek/penanggung pajaknya, sudah dapat dipersiapkan penyampaian formulir pendaftaran secara lengkap nama dan alamatnya.

2. Pengorganisasian dalam pengelolaan administrasi BPHTB yang dilakukan Dinas Pendapatan Daerah (DISPENDA) dan Badan Pertanahan Nasional (BPN) telah berjalan dengan baik. Dalam pembagian tugas pekerjaan dan pengkoordinasian tidak terdapat kendala yang besar karena pengorganisasian telah dilakukan sesuai dengan aturan dan tupoksi yang ada.

3. Penggerakan yang dilakukan Dinas Pendapatan Daerah Kota Palembang terhadap pengelolaan administrasi BPHTB masih terdapat kendala, yaitu terutama pada pelaksanaan kegiatan penyetoran belum maksimal. Dalam pengelolaan administrasi ВРHTB salah satu faktor awal yang memegang peranan penting adalah bagaimana pengetahuan masyarakat terhadap peraturan perundang-undangan yang mengatur tentang pengelolaan pajak. Dalam hal ini bagaimana pemerintah Kota 
Palembang melakukan sosialisasi agar masyarakat mengetahui maksud dan tujuan pengelolaan pajak daerah terutama untuk pajak BPHTB.

4. Pengawasan yang dilakukan Dinas Pendapatan Daerah Kota Palembang dalam melaksanakan pengelolaan administrasi BPHTB terbagi menjadi dua prosedur yaitu pengawasan melekat dan pengawasan langsung. Pengawasan melekat yaitu serangakaian kegiatan yang bersifat sebagai pengendalian yang terus menerus dilakukan oleh atasan langsung terhadap bawahannya baik secara preventif maupun represif.

\section{SARAN}

Berdasarkan kesimpulan yang telah ditemukan diatas maka ada beberapa saran yang diajukan penulis dalam Pengelolaan Administrasi Bae Perolehan Hak Atas Tanah dan Bangunan dalam meningkatkan Pendapatan Asli Daerah Kota Palembang adalah sebagai berikut:

1. Mengkaji ulang peraturan daerah tentang besaran NJOP, untuk memperoleh besaran pembayaran yang harus dikeluarkan wajib pajak.

2. Mengadakan pelatihan bagi pegawai ataupun petugas pemungut pajak.

3. Bagi pihak DISPENDA sebaiknya memberikan sosialisasi dan informasi yang lebih mendalam kepada masyarakat, terutama tentang pajak BPHTB karena pajak BPHTB merupakan pajak yang cukup besar berkontribusi terhadap PAD Kota Palembang.

4. Merubah sistem yang digunakan yakni sistem manual menjadi sistem komputerisasi agar lebih mudah dalam proses pembayaran pajak.

5. Bagi wajib pajak yang telah melanggar ketentuan yang ada, agar dapat dikenakan sanksi yang lebih tegas.

\section{DAFTAR PUSTAKA}

Achmad Tjahjono dan M.Fakhri Husein 2009, perpajakan, Edisi Keempat,UPP STIM YKPN, Yogyakarta.
Adisasmita, Rahardjo. 2011. Pengelolaan Pendapatan \& Anggaran Daerah, Yogyakarta: Graha Ilmu

Darwin. 2011. Pajak Daerah dan Retribusi Daerah, Jakarta: Mitra Wacana

Iqbal, Muhammad dan Abdul Halim. 2012. Pengelolaan Keuangan Daerah. Edisi Revisi Ketiga, Yogyakarta: UPP STIM YKPN.

Jdih, Palembang. 2012. "Peraturan Walikota No 16 Tahun 2011 Tentang Sistem dan Prosedur Pemungutan Bea Perolehan Hak Atas Tanah Dan Bangunan" diakses dari (http:/jdih.palembang.go.id/?unduh=dok umen\&id $=507$ )

Kumorotomo, Wahyudi. 2008. Desentralisasi Fiskal-Politik dan Perubahan Kebijakan 1974-2004, Jakarta: Kencana

Kuncoro, Mudrajad. 2004. Otonomi dan Pembangunan Daerah, Jakarta: Erlangga

Manua, Leon 2012, Studi Ilmu Manajemen, diakses dari (http:/studimanajemen.blogspot.co.id/20 12/08/fungsi-manajemen-menurutgeorge-terry.html)

Mardiasmo. 2002. Otonomi dan Manajemen Keuangan Daerah. Yogyakarta: Penerbit Andi

Mardiasmo 2006, perpajakan, Edisi Revisi,CV Andi Offset, Yogyakarta.

Nasution, Faisal Akbar. 2009. Pemerintahan Daerah dan Sumber-Sumber Pendapatan Asli Daerah, Jakarta: Sofmedia

Nazir, Moh. 2005. Metode Penelitian. Bogor: Ghalia Indonesia

Perwali Palembang No 16 Tahun 2011 tentang Sistem dan Prosedur Pemungutan 
Bea Perolehan Hak Atas Tanah dan Bangunan (BPHTB)

Sudirman Rismawati, SE.,M.SA dan Amiruddin Antong, SE.M.Si 2012, Perpajakan Pendekatan Teori dan Praktik, Penerbit Empat Dua Media, Malang (jawa timur)

Sugiyono. 2013. Metode Penelitian Pendidikan Pendekatan Kuntitatif Kualitatif dan $R \& D$. Bandung: Alfabeta

Suparman, Raden Agus. Nopember 2008. Undang-Undang 1945 No 20 Tahun 2000 tentang Pajak Bea Perolehan Hak Atas Tanah dan Bangunan diakses dari (http:/pajaktaxes.blogspot.com)

Surawireja, 2008. Undang-Undang 1945 No 20 Tahun 2000 tentang Pajak Bea Perolehan Hak Atas Tanah dan Bangunan diakses dari (https://surawireja.files.wordpress.com/20 08/11/uu-bphtb.pdf)

UU No 20 Tahun 2000 tentang Bea Perolehan Hak Atas Tanah dan Bangunan (BPHTB)

Waluyo 2008, Perpajakan Indonesia, Buku 1 edisi 8, Jakarta: Salemba Empat.

Wardoyo. 1980. Kamus Besar Bahasa Indonesia, Jakarta: Balai Pustaka

Yusuf, M. 2012. 8 Langkah Pengelolaan Aset Daerah Menuju Pengelolaan Keuangan daerah Terbaik. Tangerang: Salemba Empat 